\title{
Expression of vascular endothelial growth factor receptors is closely related to the histological grade of hepatocellular carcinoma
}

\author{
NOZOMI AMAOKA ${ }^{1,2}$, MASANAO SAIO ${ }^{2}$, KENICHI NONAKA $^{1,2}$, HISASHI IMAI ${ }^{1,2}$, \\ HIROYUKI TOMITA $^{1}$, FUMIO SAKASHITA ${ }^{1}$, TAKAO TAKAHASHI ${ }^{1}$, \\ YASUYUKI SUGIYAMA ${ }^{1}$, TSUYOSHI TAKAMI ${ }^{2}$ and YOSUKE ADACHI $^{1}$ \\ Departments of ${ }^{1}$ Oncologic Surgery and ${ }^{2}$ Immunopathology, Gifu University \\ Graduate School of Medicine, 1-1 Yanagido, Gifu 501-1194, Japan
}

Received January 24, 2006; Accepted March 10, 2006

\begin{abstract}
Angiogenesis is important for tumor growth, and is regulated by angiogenetic factors such as vascular endothelial growth factor (VEGF). In the present study, we investigated whether or not expression of VEGF receptors (VEGFRs) is related to the proliferation of tumor cells in hepatocellular carcinoma (HCC). We simultaneously stained proliferation marker Ki-67 antigen and either VEGFR1 (Flt1) or VEGFR2 (Flk-1) on paraffin-embedded tissue sections from 50 cases of surgically resected human HCC. Based on the staining pattern of VEGFRs, we classified the cases into 4 categories; receptor double-negative, Flt-1 single-positive, Flk-1 single-positive, receptor double-positive. Interestingly, the Ki-67 index was significantly lower in receptor doublenegative cases in comparison to that in either Flt-1 singlepositive or Flk-1 single-positive cases ( $\mathrm{P}=0.0491, \mathrm{P}=0.0196$, respectively). Moreover, the index was also significantly lower in receptor double-positive cases in comparison to either Flt-1 single-positive or Flk-1 single-positive cases ( $\mathrm{P}=0.0026, \mathrm{P}<0.0001$, respectively). We further investigated 35 cases showing a $\mathrm{Ki} 67$ index $>10 \%$ to determine the expression of VEGFRs on Ki-67 antigen-positive proliferating cells. Surprisingly, the histological grade of HCC and the expression pattern of VEGFRs showed a characteristic relation; the well-differentiated HCC cases were all distributed in the Flk-1-positive group (7/7), moderately differentiated HCC cases were distributed in either the Flt-1 or Flk-1 single-
\end{abstract}

Correspondence to: Dr Nozomi Amaoka, Department of Oncologic Surgery, Gifu University Graduate School of Medicine, 1-1 Yanagido, Gifu 501-1194, Japan

E-mail: nmhty-ama@nifty.com

Key words: hepatocellular carcinoma, vascular endothelial growth factor, VEGF receptors, Ki67, immunohistochemistry, double staining positive group (20/21), and poorly differentiated HCC cases were predominantly distributed in either the receptor doublenegative or double-positive group (6/7). These findings suggest that the expression pattern of VEGFRs influences the histological differentiation of HCC.

\section{Introduction}

Angiogenesis is crucial for the growth of solid tumor $(1,2)$. Vascular endothelial growth factor (VEGF) is well known as one of the most important factors involved in angiogenesis $(3,4)$. It has been reported that many malignant tumor cells produce VEGF and that the expression level of VEGF is well correlated with tumor growth, metastasis, and poor prognosis (5-7). Recently, anti-angiogenetic therapy utilizing inhibitors of VEGF or VEGF receptors (VEGFRs) has been enthusiastically adapted to cancer therapy and resulted in a better prognosis in combination with chemotherapeutic agents $(8,9)$. In this therapy, tumor endothelium was targeted in an attempt to block binding of VEGF to VEGFR, which resulted in slow tumor growth via inhibition of endothelial cell growth. Boocock et al first reported that VEGFR was expressed on ovarian carcinoma tissue sections and suggested that VEGF contributed to tumor growth via an autocrine mechanism (10). Recent reports support that VEGFR expressed on tumor cells and VEGF played a role in proliferation of tumor cell growth via an autocrine mechanism (11-13). They suggested that anti-angiogenetic therapy utilizing inhibitors of VEGF and VEGFRs was directly effective in inhibiting tumor growth, in addition to growth inhibition through inhibition of endothelial cell growth (13).

VEGF induces proliferation, migration and survival of endothelial cells through interaction with its receptors; VEGF receptor 1 (VEGFR1/Flt-1) and VEGF receptor 2 (VEGFR2/ Flk-1) (3). VEGFR2 is reported to induce vascular proliferation, migration, and survival (14), whereas VEGFR1 inhibits the role of VEGFR2 (15). In contrast, Yoshiji et al recently reported that blocking of VEGFR1 alone inhibited tumor growth and that blocking of VEGFR1 with anti-VEGFR2 antibody synergistically inhibited tumor growth in an animal model (16). This report suggested that VEGFR1 might induce 
Table I. Clinicopathological characteristics of 50 surgically resected HCCs used in the present study.

\begin{tabular}{|c|c|c|}
\hline Factors & & Number of patients \\
\hline Age & $\begin{array}{l}<60 \text { years } \\
\geq 60 \text { years }\end{array}$ & $\begin{array}{l}13 \\
37\end{array}$ \\
\hline Sex & $\begin{array}{l}\text { Male } \\
\text { Female }\end{array}$ & $\begin{array}{l}38 \\
12\end{array}$ \\
\hline Virus markers & $\begin{array}{l}\text { HBs } \mathrm{Ag}(+) \\
\mathrm{HCV} \mathrm{Ab} \mathrm{(+)} \\
\text { HBs Ag (-) and HCV Ab (-) }\end{array}$ & $\begin{array}{r}9 \\
40 \\
1\end{array}$ \\
\hline Liver cirrhosis & $\begin{array}{l}\text { Present } \\
\text { Absent }\end{array}$ & $\begin{array}{l}34 \\
16\end{array}$ \\
\hline Tumor size & $\begin{array}{l}\leq 40 \mathrm{~mm} \\
>40 \mathrm{~mm}\end{array}$ & $\begin{array}{l}32 \\
18\end{array}$ \\
\hline Grade of differentiation & $\begin{array}{l}\text { Well } \\
\text { Moderately } \\
\text { Poorly }\end{array}$ & $\begin{array}{r}10 \\
33 \\
7\end{array}$ \\
\hline Capsule formation & $\begin{array}{l}\text { Present } \\
\text { Absent }\end{array}$ & $\begin{array}{l}32 \\
18\end{array}$ \\
\hline Septum formation & $\begin{array}{l}\text { Present } \\
\text { Absent }\end{array}$ & $\begin{array}{r}43 \\
7\end{array}$ \\
\hline Portal vein invasion & $\begin{array}{l}\text { Present } \\
\text { Absent }\end{array}$ & $\begin{array}{l}10 \\
40\end{array}$ \\
\hline Intrahepatic metastasis & $\begin{array}{l}\text { Present } \\
\text { Absent }\end{array}$ & $\begin{array}{l}21 \\
29\end{array}$ \\
\hline
\end{tabular}

tumor proliferation by itself. Therefore, further elucidation of whether or not VEGFR1 contributes to tumor growth is warranted.

There is no report that investigates the relationship between VEGFR expression on the HCC cell and proliferation of HCC. Therefore, the aim of this study is to clarify whether or not VEGFR expression correlates with tumor cell proliferation in vivo using tissue sections from hepatocellular carcinoma patients. We simultaneously observed VEGFR1 or VEGFR2 expression in combination with cellular proliferation marker Ki67 expression on tissue sections from hepatocellular carcinoma patients.

\section{Materials and methods}

Patients. Tissue samples from fifty cases of surgically resected hepatocellular carcinoma (HCC) (between January 1998 and December 2003) at Gifu University hospital were analyzed in this study. These cases were numbered chronologically. There were 38 males and 12 females, and the average patient age was 66.4 years (range, 41 to 85 years.). Patients with a history of hepatectomy or preoperative chemotherapy were excluded from the analysis. Clinicopathological factors of analyzed patients were classified according to the criteria of the Japanese Research Council on Hepatocellular Carcinoma and summerized in Table I. The analyses were performed according to the guidelines of the ethics committee of Gifu University School of Medicine.
Immunohistochemical analyses. Surgically resected samples were fixed in $10 \%$ paraformaldehyde in phosphate buffered saline (PBS) for $24 \mathrm{~h}$, then paraffin-embedded tissue blocks were prepared. Three $\mu \mathrm{m}$-thick sections were prepared and submitted for standard dewaxing and hydration processes. Sections were immersed into $10 \mathrm{mM}$ citrate buffer, $\mathrm{pH} 7.0$, then autoclaved for $20 \mathrm{~min}$ at $121^{\circ} \mathrm{C}$. After washing with double distilled water (D.D.W.), the section was dried using a fan, and the outline of the section was marked using a PAP pen (Dako Cytomations Japan, Kyoto). After an additional 30 -min drying process, the section was rinsed with $0.3 \%$ skim milk in $50 \mathrm{mM}$ Tris- $\mathrm{HCl}, \mathrm{pH} 7.6$ (Tris buffer), then rinsed with Tris buffer to remove excess skim milk from the section. After shaking off the Tris buffer, 1-50x diluted antiFlk-1 mouse monoclonal antibody (sc-6251, Santa Cruz Biotechnology, Inc., Santa Cruz, CA), or diluted anti-Flt-1 rabbit polyclonal antibody (Spring Bioscience, Fremont, $\mathrm{CA})$, was applied to the section at room temperature $(\mathrm{R} / \mathrm{T})$ and incubated for $1 \mathrm{~h}$ in a humidified chamber. After washing with Tris buffer for 3x $10 \mathrm{~min}$, either alkaline phosphatase conjugated goat anti-mouse IgG, Histofine Simple Stain AP (M) (Nichirei, Tokyo, Japan), or alkaline phosphatase conjugated sheep anti-rabbit IgG, Histofine Simple Stain AP (R) (Nichirei) was applied for $1 \mathrm{~h}$ at R/T. After washing with Tris buffer for $3 \times 10 \mathrm{~min}$, the reaction was visualized with Dako New Fuchsin substrate system (Dako Cytomations Japan). To terminate the reaction, the section was submerged into $4 \%$ paraformaldehyde in Tris 
A
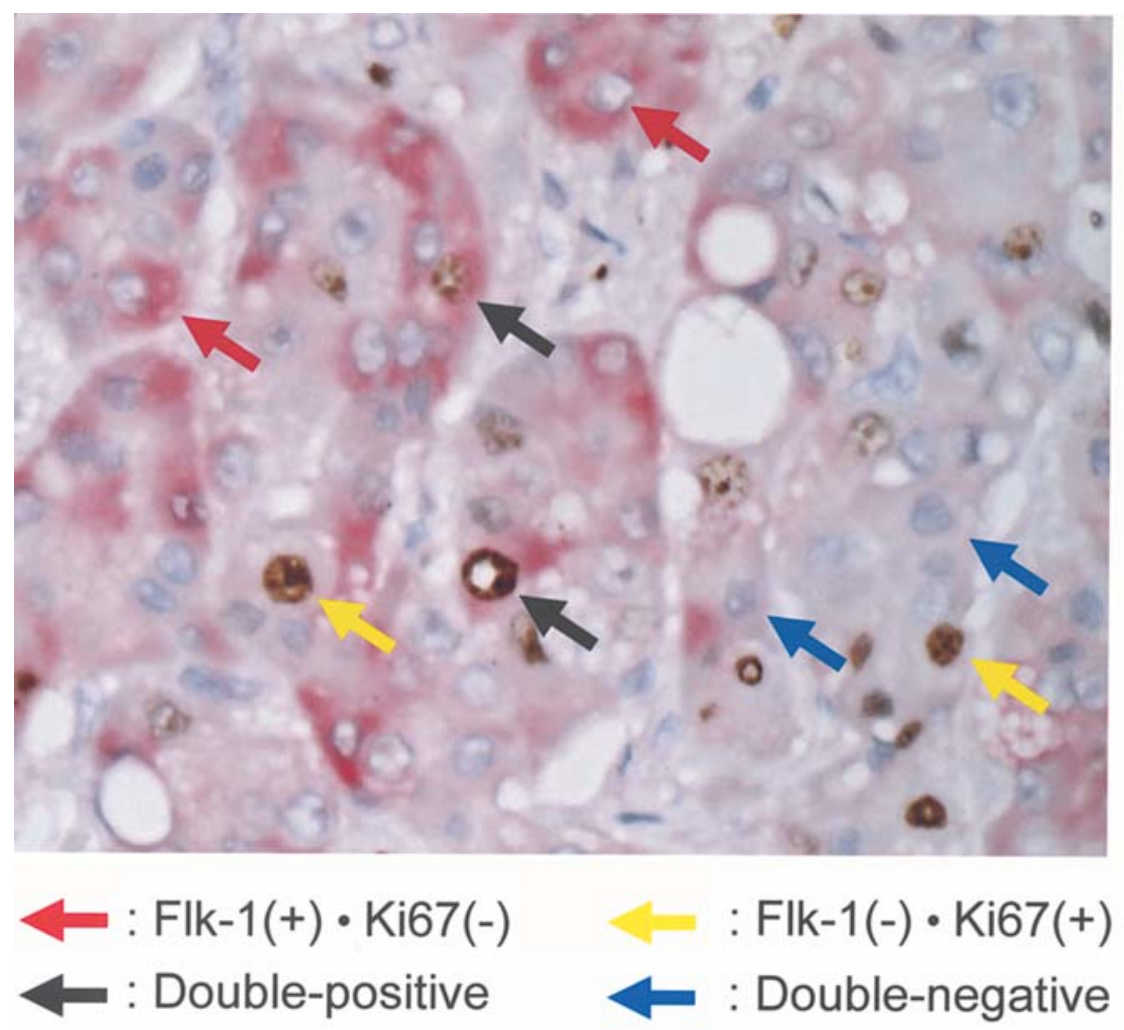

B

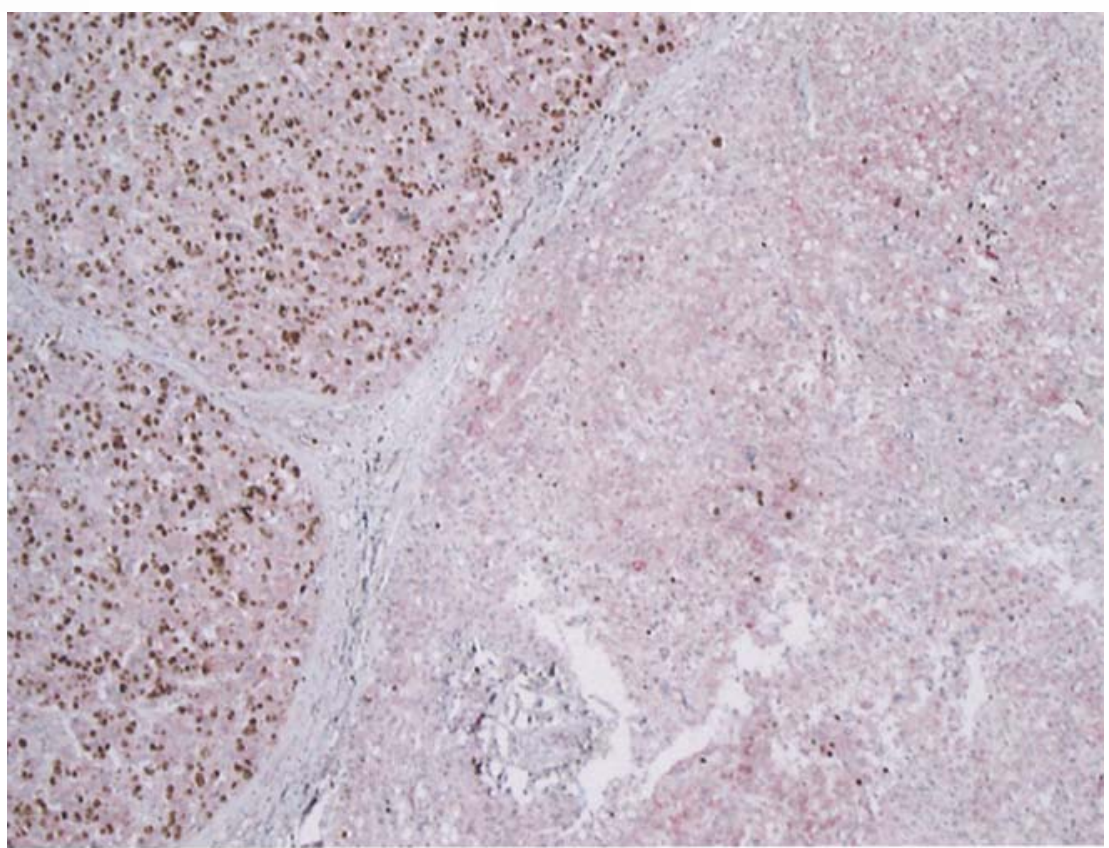

\section{red : Flk-1, brown : Ki67}

Figure 1. Immunohistochemical double staining of VEGFR2 and Ki67. (A) Case 44 is shown as a representative staining pattern. Intra-cytoplasmic staining of Flk-1 is observed as red, and nuclear staining of Ki-67 antigen is observed as brown. The red arrows indicate Flk-1(+)-Ki67(-) cells, yellow arrows indicate Flk-1(-)-Ki67(+) cells, black arrows indicate double-positive cells, and blue arrows indicate double-negative cells. (B) In this case (case 31$)$, the Ki67 index obviously differed at various sites within the nodule. Therefore, we analyzed areas of the nodule independently.

buffer for 10 min and washed with Tris buffer for 3x 10 min and stored at $4^{\circ} \mathrm{C}$ in the dark until the next step was performed.

For Ki67 staining, an Flt-1 or Flk-1 stained section was submerged into $10 \mathrm{mM}$ citrate buffer, $\mathrm{pH} 7.0$, then autoclaved at $121^{\circ} \mathrm{C}$ for $20 \mathrm{~min}$ to degenerate the antibody previously reacted on the section. After rinsing with D.D.W., the specimen was dried and submerged in $0.3 \%$ hydrogen peroxide in Tris buffer for $20 \mathrm{~min}$ at $\mathrm{R} / \mathrm{T}$ to block endogeneous peroxidase activity.

After washing with Tris buffer for $3 \times 10$ min, the section was rinsed with $0.3 \%$ skim milk in Tris buffer, then rinsed with Tris buffer to remove excess skim milk from the section. 
A

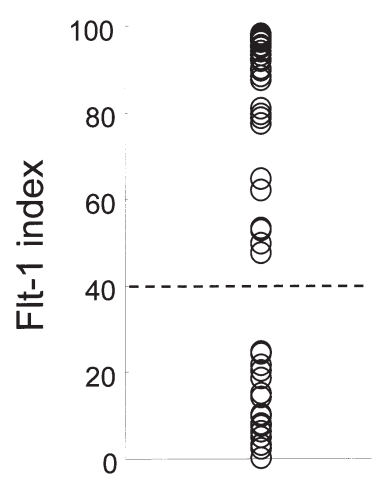

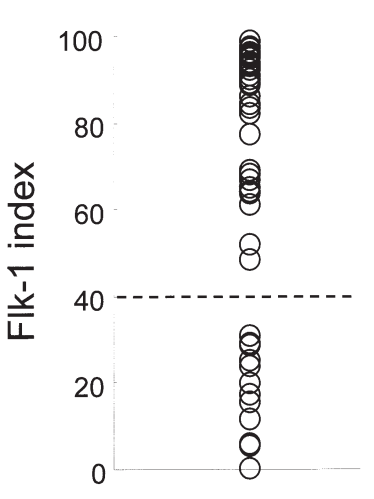

B

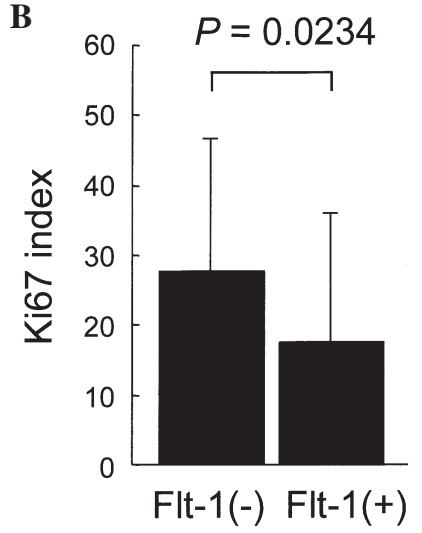

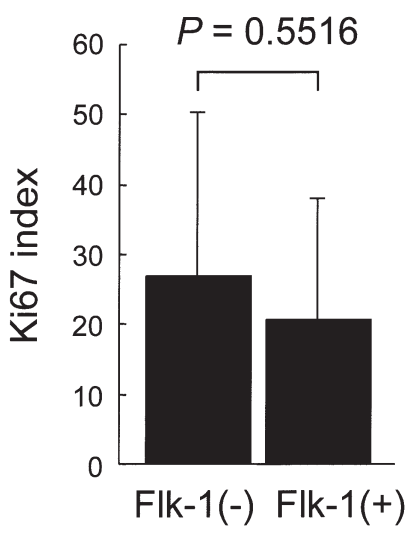

Figure 2. Analyses of VEGFR distribution and Ki67 index on HCC specimens. (A) Distribution of Flt-1 index and Flk-1 index in HCC specimens. Specimens showing $<40 \%$ in either index were termed either Flt-1-negative or Flk-1-negative, the remaining specimens were termed either Flt-1-positive or Flk-1positive. (B) Ki67 index was compared with Flt-1- or Flk-1-negative group versus the positive group.

After shaking off the Tris buffer, 1-50x diluted anti-Ki67 mouse monoclonal antibody (clone MIB-1, Dako Cytomations Japan) was applied to the section and incubated for $1 \mathrm{~h}$ at $\mathrm{R} / \mathrm{T}$. After washing with Tris buffer for $3 \times 10$ min, horse radish peroxidase conjugated goat anti-mouse IgG, Histofine Simple Stain PO (M) (Nichirei) was applied for $1 \mathrm{~h}$ at R/T. After washing with Tris buffer for $3 \times 10 \mathrm{~min}$, the reaction was visualized with $0.03 \%$ 3,3'-diaminobenzidine, tetrahydrochloride, $0.3 \%$ hydrogen peroxide in Tris buffer. After fixing with 4\% paraformaldehyde in Tris buffer for $10 \mathrm{~min}$, regular nuclear staining with hematoxylin and a dehydration process were performed and the section was submitted for observation.

Assesment of the stained sections. To assess specimens, each sample was observed at magnification of x400, and all tumor cells observed in 5 fields were counted. All tumor cells were classified into 4 classes according to the staining for Flt-1, Flk-1, and Ki67; Flt- $1^{+} \mathrm{Ki} 67^{+}$, Flt-1 ${ }^{+} \mathrm{Ki} 67^{-}$, Flt-1-Ki67+, and Flt-1-Ki67- cells for Flt-1 and Ki67 double-stained specimens, and Flk-1+Ki67+, Flk-1+Ki67-, Flk-1-Ki67 ${ }^{+}$, and Flk-1-Ki67cells for Flk-1 and Ki67 double-stained specimens respectively. Flt-1 or Flk-1 index was defined as Flt-1- or Flk-1-positive cells versus total tumor cells. Ki67 index was defined as Ki67positive cells versus total tumor cells.

Statistical analyses. Mann-Whitney's U-test was performed and a $\mathrm{p}<0.05$ was considered significant.

\section{Results}

Ki67 index was significantly lower in Flt-1-positive cases. Fig. 1A shows the staining pattern for a Flk-1 and Ki67 doublestained HCC section (case 44). Among the 50 cases, there were tumor nodules with different staining patterns for either Ki67, Flt-1 or Flk-1 despite confirmation of non-necrotic area. In these cases, we analyzed each nodule independently, 55 nodules in total (Fig. 1B).

Fig. 2A shows the Flt-1 or Flk-1 index in all cases. The Flt- 1 index was distributed from 0 to $98 \%$ (average, $47.7 \pm 40.4 \%$ ), and Flk-1 index was distributed from 0 to $99 \%$ (average, $64.5 \pm 34.7 \%$ ). There appeared to be gaps at $40 \%$ in both the Flt-1 and Flk-1 indices. Therefore, we sub-classified the groups showing $>40 \%$ on the Flt- 1 index as Flt-1-positive and $<40 \%$ on the Flt- 1 index as Flt-1-negative, $>40 \%$ on the Flk-1 index as Flk-1-positive, and $<40 \%$ on the Flk- 1 index as Flk-1-negative group. Based on this sub-classification, the percentage in the Flt-1-positive group was $52.7 \%$ (29 of 55 specimens), and the percentage in the Flk-1-positive group was $72.7 \%$ (40 of 55 specimens) (Fig. 2A). Ki67 index in all cases was distributed from 2 to $85 \%$ (average, $23.2 \pm 20.6 \%$ ).

Fig. 2B shows that the distribution of Ki67 index among each sub-class was $27.7 \pm 19.1 \%$ in Flt-1-negative cases, $17.6 \pm 18.3 \%$ in Flt-1-positive cases, $26.8 \pm 23.5 \%$ in Flk-1negative cases, and $20.7 \pm 17.3 \%$ in Flk-1-positive cases. There was a significant difference in the Ki67 index between the Flt-1-negative group and Flt-1-positive group ( $\mathrm{P}=0.0234)$.

Ki67 index was significantly low in the Flt-1 and Flk-1 double-positive cases based on sub-classification of VEGF receptor expression pattern. We aligned the sections in sequence and analyzed Flt-1 and Flk-1 distribution patterns in the same tumor nodules. Then we analyzed the Ki67 index of the same tumor nodules in relation to the Flt-1 and Flk-1 findings (Fig. 3A). As shown in Fig. 3B, the Ki67 index in specimens that were receptor double-negative, Flt-1 singlepositive, Flk-1 single-positive, and receptor double-positive was $17.3 \pm 21.0 \%, 37.6 \pm 22.9 \%, 32.3 \pm 16.8 \%, 11.2 \pm 10.9 \%$, respectively. There was a significantly lower Ki67 index in receptor double-negative cases in comparison to that in either Flt-1 or Flk-1 single-positive case $(\mathrm{P}=0.0491, \mathrm{P}=0.0196$, respectively). Interestingly, the Ki67 index in receptor doublepositive cases was also significantly lower in comparison to either Flt-1 or Flk-1 single-positive groups $(\mathrm{P}=0.0026$, $\mathrm{P}<0.0001$, respectively) (Fig. 3B).

Fig. 3C shows a representative case in which the Ki67 index was higher in the Flt-1 single-positive area in comparison to that in the receptor double-negative area. Fig. 3D shows a representative case in which the Ki67 index was higher in an Flk-1 single-positive area in comparison to that in the receptor double-positive area.

Histological grade of HCC was well related to VEGFR expression pattern in proliferative phase HCC cells. Because we stained the VEGF receptor and Ki67 simultaneously on 
A

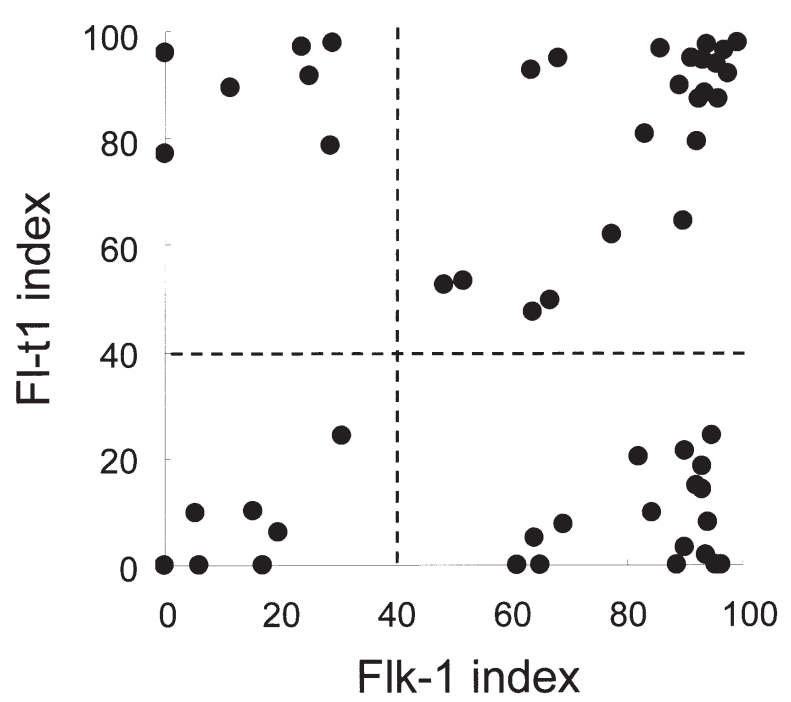

C

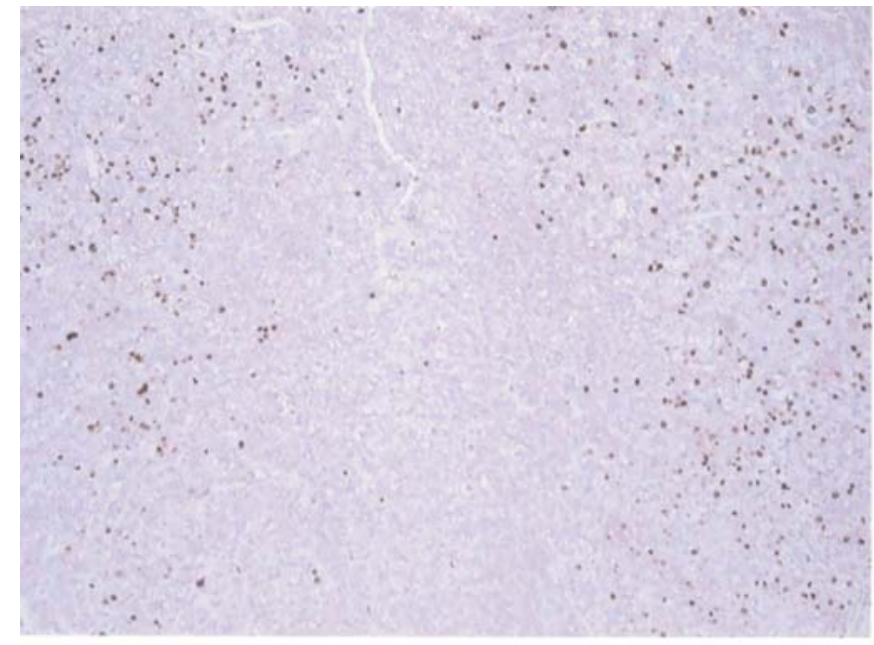

red : Flk-1, brown : Ki67

D

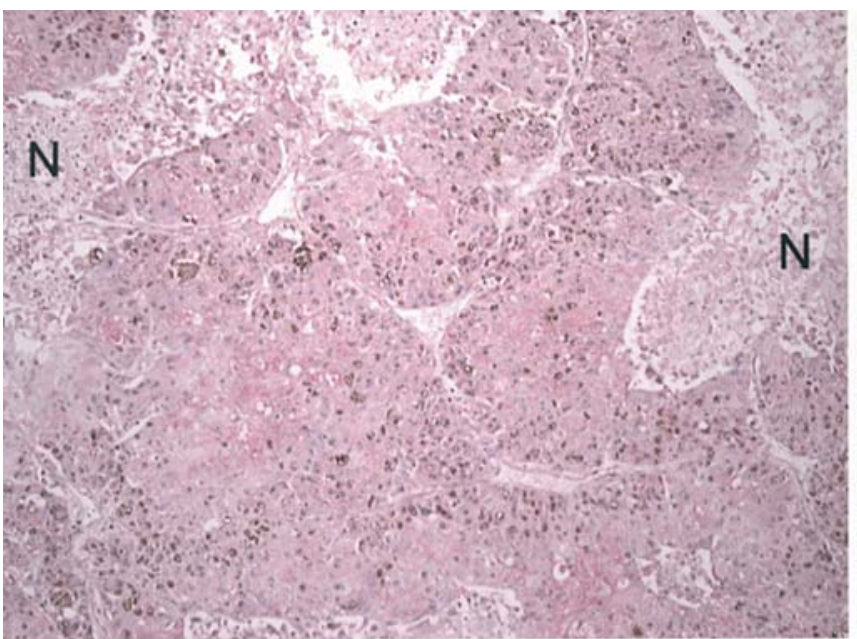

red : Flk-1, brown : Ki67
B
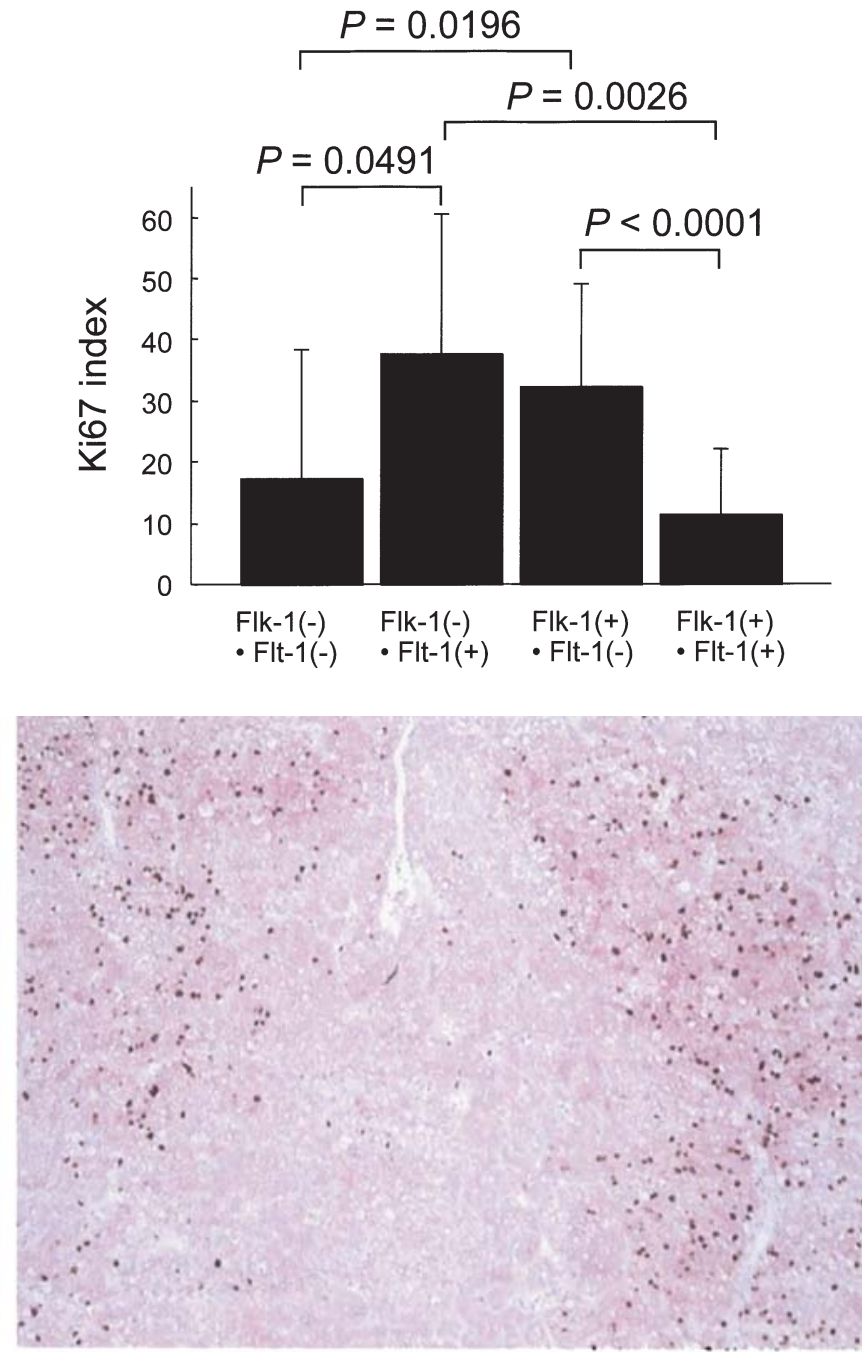

red: Flt-1, brown : Ki67

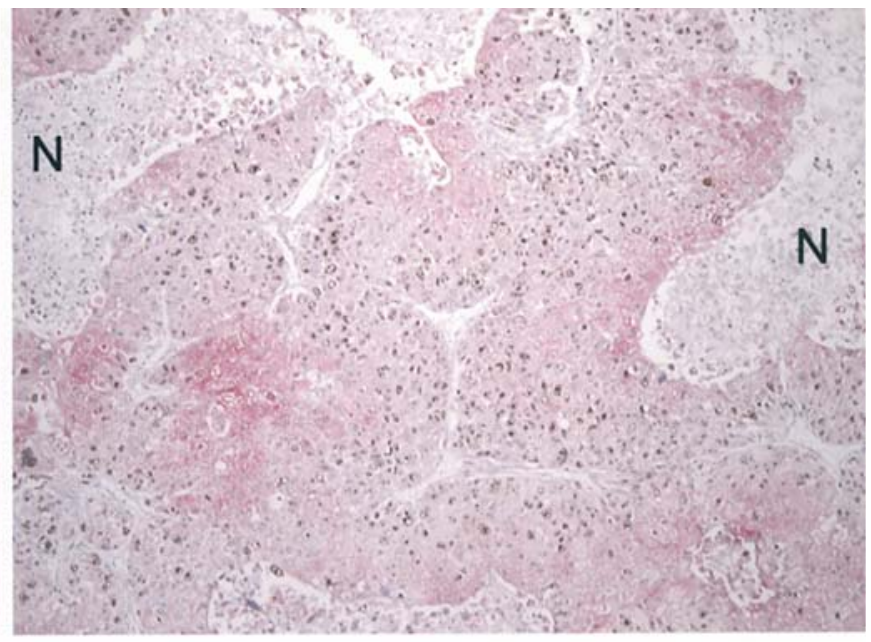

red: Flt-1, brown : Ki67

Figure 3. Analyses of Ki67 index based on VEGF receptor expression on HCC specimens. (A) Each specimen was classified based on the Flt-1 and Flk-1 indices. The cut-off between each group was less than or more than $40 \%$ for each index. (B) Ki67 index was compared in each group. (C) A representative case showing both an Flk-1(-)-Flt-1(+) area and an Flk-1(-)-Flt-1(-) area in the same specimen (case 50). The former area showed a high Ki67 index and the latter area showed a low Ki67 index. (D) A representative case showing both an Flk-1(+)-Flt-1(+) area and an Flk-1(+)-Flt-1(-) area in the same specimen (case 17). The former area showed a low Ki67 index and the latter area showed a high Ki67 index. N indicates a necrotic area, which was excluded from analysis. 
A
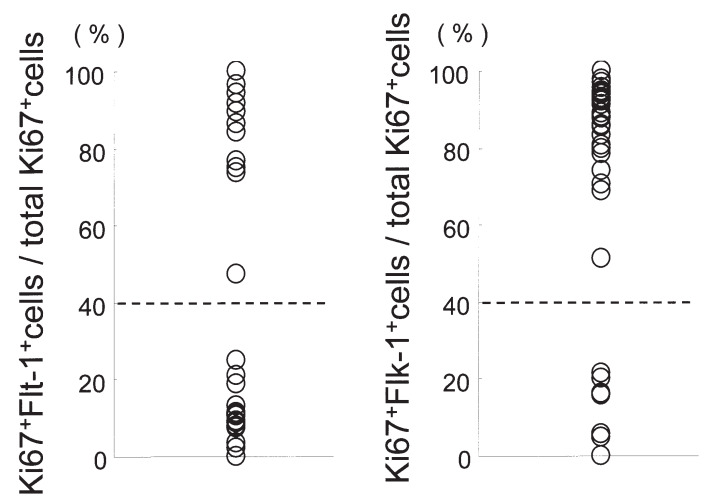

B

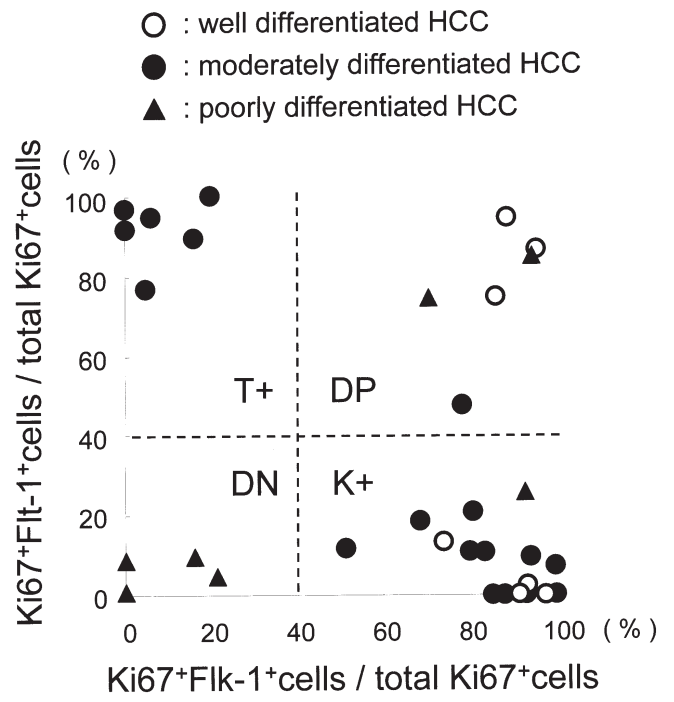

Figure 4. VEGF receptor distributions in Ki67-positive cells and relation with histological differentiation. (A) Ki67-positive in each specimen were classified based on the Flt-1 and Flk-1 indices. The cut-off between each group was less than or more than $40 \%$ of each index. (B) Combined distribution of Flt-1 and Flk-1 index in Ki67-positive cells. DN; Flt-1 and Flk-1 double-negative group, T+; Flt-1(+)-Flk-1(-) group, K+; Flt-1(-)-Flk1(+) group, and DP; Flt-1 and Flk-1 double-positive group. In terms of histological differentiation, open circle indicate well-differentiated HCC, filled circles indicate moderately differentiated $\mathrm{HCC}$, and filled triangles indicate poorly differentiated HCC.

the same section, we tried to evaluate Ki67-positive cells for Flt-1 or Flk-1 index. For this purpose, we selected 35 cases in which the total Ki67 index of both Flk-1 double-stained and Flt-1 double-stained sections was $>10 \%$. As shown in Fig. 4A, the Flt-1 index was distributed from 0 to $100 \%$ (average, $34.0 \%$ ) in Ki67-positive cells. While, the Flk-1 index was distributed from 0 to $100 \%$ (average, $63.5 \%$ ) in Ki67positive cells. When we selected $40 \%$ as the cut-off for Flt-1or Flk-1-positive groups, the Flt-1-positive cases comprised $37.1 \%$ (13/35), while Flk-1-positive cases comprised $71.4 \%$ $(25 / 35)$, respectively.

On the other hand, both receptor double-negative cases comprised $11.4 \%$ (4/35), Flt-1-single-positive cases comprised $17.1 \%$ (6/35), Flk-1-single-positive cases comprised $54.3 \%$ $(16 / 35)$, and both receptor-positive cases comprised $17.1 \%$ $(6 / 35)$, respectively. That is, Ki67-positive cells tended to show an Flk-1 single-positive phenotype (Fig. 4B). In addition, based on the histological differentiation analysis, moderately differentiated hepatocellular carcinoma tended to show Flt-1 single-positive or Flk-1 single-positive phenotypes (100 and $73.7 \%$ respectively), while all 4 receptor double-negative cases showed poorly differentiated hepatocellular carcinoma (Fig. 4B).

\section{Discussion}

VEGF plays a role in the induction of proliferation of endothelial cells through its receptors (3). VEGF expression was initially identified in endothelial cells, and was considered specific in endothelial cells (17-19). However, VEGF was later reported to be expressed on monocytes (20), melanoma, bladder cancer and breast tumor cells (11-13), and autocrine process of VEGF and its receptors is important to maintain proliferation of tumor cells (11-13). Although Yamaguchi et al reported that hepatocellular carcinoma cells did not express either Flt-1 or Flk-1 (21), VEGF receptor expression was reported in head and neck cancer, prostate cancer, and gastric cancer tissue (22-24). Although there are many VEGF receptors including VEGFR-1 (Flt-1), VEGFR2 (Flk-1), VEGFR-3 (Flt-3), and Neurophilin-1 (NP-1), there have been many reports related to the functions of VEGFR-1 and VEGFR-2 (25-31). In the present study, we examined Flt-1 and Flk-1 expression on HCC tissue sections and showed the expression of Flt-1 and Flk-1 on the paraffinembedded tissue sections. Fig. 3B shows both Flt-1 singlepositive cases and Flk-1 single-positive cases to have a higher Ki67 index in comparison to that on receptor doublenegative cases. In addition, Ki67 index was significantly lower in both receptor double-positive cases in comparison to that in single-positive cases. These data suggest that either Flt-1 or Flk-1 receptor single-positive phenotype would be important for carcinoma cell growth because the receptor double-negative phenotype showed a low Ki67 index. In addition, our data also suggested that the expression of either receptor on the tumor cells would interfere with the cell growth induced by the other.

To clarify our findings, we must discuss the present understanding of Flk-1 and Flt-1. Shalby et al suggested that Flk-1 played a role in the proliferation of endothelial cells utilizing Flk-1 null mice (32). Takahashi et al showed that Flk-1 activation through VEGF resulted in proliferation of endothelial cells (14). Moreover, Wu et al also reported the Flk-1 mediated proliferation of bladder tumor cells (13).

However, the role of Flt-1 in cell proliferation remains contradictory. Fong et al suggested that Flt-1 played a role in angiogenesis but did not in proliferation of endothelial cells utilizing Flt-1 null mice (33). Park et al showed that Flt-1 itself was not directly related to proliferation, but it did participate in cell growth inhibition of Flk-1-mediated cellproliferation as a decoy receptor (34). Zeng et al showed that Flt-1 inhibits Flk-1-mediated proliferation signals (35). Landgren et al showed that Flt-1 could induce cell proliferation in combination with placental growth factor (PLGF), the expression of which is restricted to the placenta (36). Fan et al showed that Flt-1 expression in colon cancer cells was not related to proliferation but rather to migration, invasion or colony formation (37).

Therefore, the above reports support our findings that Flk-1 single-positive cases had a high Ki67 index, while Flt-1 
and Flk-1 double-positive cases had a low Ki67 index. Based on finding that Flt-1 single-positive cases had a high Ki67 index, Flt-1 may be related to cell proliferation in hepatocellular carcinoma. However, the mechanism of how Flt-1 single expression would contribute to inducing the $\mathrm{Ki}^{+} 7^{+}$ proliferation phase in tumor cells is not obvious. Regarding this point, Vincent et al reported that Flt-1 played a role in cellular proliferation in primary multiple myeloma cells that express Flt-1 but Flk-1 does not (38). Thus, our findings, and collectively suggest that Flt-1 induces proliferation signals only when Flt-1 is expressed alone.

Ki67 can label the cell in the proliferative phase (S, G2, M, and G1), and indicates cell proliferative activity (39). In this study, we evaluated the relationship between tumor cell proliferative activity and Flt-1 or Flk-1 expression in formalinfixed paraffin-embedded tissue sections because the localization of Ki67 antigen and VEGFR ( Flt-1 or Flk-1) differ, with the former being located in the nucleus and the latter in the cytoplasm. That is, our double-staining procedure would be useful to evaluate the relationship between proliferation activity and another factor that is not located to the nucleus.

Xie et al performed Ki67 and VEGF double-staining for breast cancer tissue implanted in rats, and showed the correlation of VEGF expression and Ki67-staining (40). Although they examined the correlation of Ki67 expression and Flk-1 or Flt-1 expression, they did not examine many different cases. Regarding this point, our double-staining methods for human paraffin-embedded tissue sections were very useful, providing new knowledge that not only Flk-1 but also Flt-1 might participate in proliferation of hepatocellular carcinoma cell growth, when Flt-1 is expressed without Flk-1 expression.

The discussion cited above speculated on whether VEGFR expression is related to the $\mathrm{Ki} 67$ index. Because we stained Ki67 antigen and VEGFR simultaneously on the same sections, we were able to demonstrate that Ki67-positive cells showed characteristic patterns of VEGFR expressions. Interestingly, this analysis showed that there was a relation between the VEGFR expression patterns and the degree of histological differentiation (Fig. 4C). That is, moderately differentiated HCC cells in the proliferative phase tended to express either Flt-1 or Flk-1 alone. However, poorly differentiated HCC cells in the proliferative phase tended to show Flt-1 and Flk-1 double-negative or double-positive expression pattern. Moreover, well differentiated HCC cells in the proliferative phase tended to show the Flk-1- positive phenotype, regardless of the Flt-1 expression. Indeed, Ferrer et al observed a relationship between histological grade and Flk-1 expression in human prostate cancer tissue sections (22).

Several reports suggested that VEGF expression was related to hepatocarcinogenesis from the early stages $(41,42)$. In addition, VEGF expression is increased in aberrant expression of tumor suppressor p53, which is frequently shown in moderately or poorly differentiated HCC but not in welldifferentiated HCC $(43,44)$. Therefore, the present findings were very interesting because the VEGFR expression pattern in proliferating carcinoma cells correlated well with the histological grade.

In conclusion, in the present study, we showed the relationship between histological grade of HCC and expression pattern of VEGFRs in addition to showing the relationship between VEGFR expression and Ki67 index. This is the first report to show a relationship between histological grade of HCC and VEGFR expression pattern in relation to the proliferative activity of tumor cells by staining Ki67 and VEGFR simultaneously in the same sections.

\section{References}

1. Ziche M and Gullino PM: Angiogenesis and neoplastic progression in vitro. J Natl Cancer Inst 69: 483-487, 1982.

2. Folkman J: What is the evidence that tumors are angiogenesis dependent? J Natl Cancer Inst 82: 4-6, 1990.

3. Ferrara N: Vascular endothelial growth factor: basic science and clinical progress. Endocr Rev 25: 581-611, 2004.

4. Senger DR, Van de Water L, Brown LF, et al: Vascular permeability factor (VPF, VEGF) in tumor biology. Cancer Metastasis Rev 12: 303-324, 1993.

5. Takahashi Y, Kitadai Y, Bucana CD, Cleary KR and Ellis LM: Expression of vascular endothelial growth factor and its receptor, KDR, correlates with vascularity, metastasis, and proliferation of human colon cancer. Cancer Res 55: 3964-3968, 1995.

6. Mise M, Arii S, Higashituji H, et al: Clinical significance of vascular endothelial growth factor and basic fibroblast growth factor gene expression in liver tumor. Hepatology 23: 455-464, 1996.

7. Yoshiji H, Gomez DE, Shibuya M and Thorgeirsson UP: Expression of vascular endothelial growth factor, its receptor, and other angiogenic factors in human breast cancer. Cancer Res 56: 2013-2016, 1996.

8. Hurwitz H, Fehrenbacher L, Novotny W, et al: Bevacizumab plus irinotecan, fluorouracil, and leucovorin for metastatic colorectal cancer. N Engl J Med 350: 2335-2342, 2004.

9. Peterson AC, Swiger S, Stadler WM, Medved M, Karczmar G and Gajewski TF: Phase II study of the Flk-1 tyrosine kinase inhibitor SU5416 in advanced melanoma. Clin Cancer Res 10: 4048-4054, 2004.

10. Boocock CA, Charnock-Jones DS, Sharkey AM, et al: Expression of vascular endothelial growth factor and its receptors flt and KDR in ovarian carcinoma. J Natl Cancer Inst 87: 506-516, 1995.

11. Gitay-Goren H, Halaban R and Neufeld G: Human melanoma cells but not normal melanocytes express vascular endothelial growth factor receptors. Biochem Biophys Res Commun 190: 702-708, 1993.

12. De Jong JS, van Diest PJ, van der Valk P and Baak JP: Expression of growth factors, growth inhibiting factors, and their receptors in invasive breast cancer. I: An inventory in search of autocrine and paracrine loops. J Pathol 184: 44-52, 1998.

13. Wu W, Shu X, Hovsepyan H, Mosteller RD and Broek D: VEGF receptor expression and signaling in human bladder tumors. Oncogene 22: 3361-3370, 2003.

14. Takahashi T, Ueno $\mathrm{H}$ and Shibuya M: VEGF activates protein kinase C-dependent, but Ras-independent Raf-MEK-MAP kinase pathway for DNA synthesis in primary endothelial cells. Oncogene 18: 2221-2230, 1999.

15. Roberts DM, Kearney JB, Johnson JH, Rosenberg MP, Kumar R and Bautch VL: The vascular endothelial growth factor (VEGF) receptor Flt-1 (VEGFR-1) modulates Flk-1 (VEGFR-2) signaling during blood vessel formation. Am J Pathol 164: 1531-1535, 2004.

16. Yoshiji H, Kuriyama S, Yoshii J, et al: Involvement of the vascular endothelial growth factor receptor-1 in murine hepatocellular carcinoma development. J Hepatol 41: 97-103, 2004.

17. Plouet $\mathrm{J}$ and Moukadiri H: Characterization of the receptor to vasculotropin on bovine adrenal cortex-derived capillary endothelial cells. J Biol Chem 265: 22071-22074, 1990.

18. Vaisman N, Gospodarowicz D and Neufeld G: Characterization of the receptors for vascular endothelial growth factor. J Biol Chem 265: 19461-19466, 1990.

19. Jakeman LB, Winer J, Bennett GL, Altar CA and Ferrara N: Binding sites for vascular endothelial growth factor are localized on endothelial cells in adult rat tissues. J Clin Invest 89: 244-253, 1992.

20. Shen H, Clauss M, Ryan J, et al: Characterization of vascular permeability factor/vascular endothelial growth factor receptors on mononuclear phagocytes. Blood 81: 2767-2773, 1993. 
21. Yamaguchi R, Yano H, Nakashima Y, et al: Expression and localization of vascular endothelial growth factor receptors in human hepatocellular carcinoma and non-HCC tissues. Oncol Rep 7: 725-729, 2000.

22. Ferrer FA, Miller LJ, Lindquist R, Kowalczyk P, Laudone VP, Albertsen PC and Kreutzer DL: Expression of vascular endothelial growth factor receptors in human prostate cancer. Urology 54: 567-572, 1999.

23. Lalla RV, Boisoneau DS, Spiro JD and Kreutzer DL: Expression of vascular endothelial growth factor receptors on tumor cells in head and neck squamous cell carcinoma. Arch Otolaryngol Head Neck Surg 129: 882-888, 2003.

24. Zhang H, Wu J, Meng L and Shou CC: Expression of vascular endothelial growth factor and its receptors KDR and Flt-1 in gastric cancer cells. World J Gastroenterol 8: 994-998, 2002.

25. De Vries C, Escobedo JA, Ueno H, Houck K, Ferrara N and Williams LT: The fms-like tyrosine kinase, a receptor for vascular endothelial growth factor. Science 255: 989-991, 1992.

26. Millauer B, Wizigmann-Voos S, Schnurch H, Martinez R, Moller NP, Risau W and Ullrich A: High affinity VEGF binding and developmental expression suggest Flk-1 as a major regulator of vasculogenesis and angiogenesis. Cell 72: 835-846, 1993.

27. Pajusola K, Aprelikova O, Korhonen J, Kaipainen A, Pertovaara L, Alitalo R and Alitalo K: FLT4 receptor tyrosine kinase contains seven immunoglobulin-like loops and is expressed in multiple human tissues and cell lines. Cancer Res 52: 5738-5743, 1992.

28. Quinn TP, Peters KG, De Vries C, Ferrara N and Williams LT: Fetal liver kinase 1 is a receptor for vascular endothelial growth factor and is selectively expressed in vascular endothelium. Proc Natl Acad Sci USA 90: 7533-7537, 1993.

29. Shibuya M, Yamaguchi S, Yamane A, Ikeda T, Tojo A, Matsushime $\mathrm{H}$ and Sato $\mathrm{M}$ : Nucleotide sequence and expression of a novel human receptor-type tyrosine kinase gene (flt) closely related to the fms family. Oncogene 5: 519-524, 1990

30. Soker S, Takashima S, Miao HQ, Neufeld G and Klagsbrun M: Neuropilin-1 is expressed by endothelial and tumor cells as an isoform-specific receptor for vascular endothelial growth factor. Cell 92: 735-745, 1998.

31. Terman BI, Dougher-Vermazen M, Carrion ME, Dimitrov D, Armellino DC, Gospodarowicz D and Bohlen P: Identification of the KDR tyrosine kinase as a receptor for vascular endothelial cell growth factor. Biochem Biophys Res Commun 187: 1579-1586, 1992.

32. Shalaby F, Rossant J, Yamaguchi TP, Gertsenstein M, Wu XF, Breitman ML and Schuh AC: Failure of blood-island formation and vasculogenesis in Flk-1-deficient mice. Nature 376: 62-66, 1995.

33. Fong GH, Rossant J, Gertsenstein M and Breitman ML: Role of the Flt-1 receptor tyrosine kinase in regulating the assembly of vascular endothelium. Nature 376: 66-70, 1995.
34. Park JE, Chen $\mathrm{HH}$, Winer J, Houck KA and Ferrara N Placenta growth factor. Potentiation of vascular endothelial growth factor bioactivity, in vitro and in vivo and high affinity binding to Flt-1 but not to Flk-1/KDR. J Biol Chem 269: 25646-25654, 1994.

35. Zeng H, Dvorak HF and Mukhopadhyay D: Vascular permeability factor (VPF)/vascular endothelial growth factor (VEGF) receptor-1 down-modulates VPF/VEGF receptor-2mediated endothelial cell-proliferation, but not migration, through phosphatidylinositol 3-kinase-dependent pathways. J Biol Chem 276: 26969-26979, 2001.

36. Landgren E, Schiller P, Cao Y and Claesson-Welsh L: Placenta growth factor stimulates MAP kinase and mitogenicity but not phospholipase C-gamma and migration of endothelial cells expressing Flt 1. Oncogene 16: 359-367, 1998.

37. Fan F, Wey JS, McCarty MF, et al: Expression and function of vascular endothelial growth factor receptor- 1 on human colorectal cancer cells. Oncogene 24: 2647-2653, 2005.

38. Vincent L, Jin DK, Karajannis MA, et al: Fetal stromal-dependent paracrine and intracrine vascular endothelial growth factor-a/ vascular endothelial growth factor receptor-1 signaling promotes proliferation and motility of human primary myeloma cells. Cancer Res 65: 3185-3192, 2005.

39. Yu CC, Woods AL and Levison DA: The assessment of cellular proliferation by immunohistochemistry: a review of currently available methods and their applications. Histochem J 24: 121-131, 1992.

40. Xie B, Tam NN, Tsao SW and Wong YC: Co-expression of vascular endothelial growth factor (VEGF) and its receptors (flk-1 and flt-1) in hormone-induced mammary cancer in the Noble rat. Br J Cancer 81: 1335-1343, 1999.

41. Yoshiji H, Kuriyama S, Yoshii J, et al: Halting the interaction between vascular endothelial growth factor and its receptors attenuates liver carcinogenesis in mice. Hepatology 39: 1517-1524, 2004.

42. Park YN, Kim YB, Yang KM and Park C: Increased expression of vascular endothelial growth factor and angiogenesis in the early stage of multistep hepatocarcinogenesis. Arch Pathol Lab Med 124: 1061-1065, 2000

43. Mukhopadhyay D, Tsiokas L and Sukhatme VP: Wild-type p53 and $\mathrm{v}$-Src exert opposing influences on human vascular endothelial growth factor gene expression. Cancer Res 55: 6161-6165, 1995.

44. Murakami Y, Hayashi K, Hirohashi S and Sekiya T: Aberrations of the tumor suppressor p53 and retinoblastoma genes in human hepatocellular carcinomas. Cancer Res 51: $5520-5525,1991$. 